\title{
Of Goats ANd Men: A Literary Relic of Gaelic ONTARIO
}

\begin{abstract}
Michael Newton $^{*}$
The settlement of Scottish Gaels that began after the American Revolution in the far eastern corner of Ontario known historically as Glengarry County has long been the subject of popular and scholarly commentary. ${ }^{1}$ Despite the promising start made by the late Professor Charles Dunn of Harvard University from the 1940s through 1960s to record, edit, analyze and publish the Gaelic oral traditions of Canada, ${ }^{2}$ including those of Glengarry, only a very small number of texts from the Highland communities of Ontario have been given a thorough treatment as either historical evidence or literature.

The following poem is one of the longest surviving Scottish Gaelic poems composed in Canada. ${ }^{3}$ It does not seem to have

* Dr. Michael Newton was awarded a Ph.D. in Celtic Studies from the University of Edinburgh in 1998 and has written several books and numerous articles on many aspects of Highland culture and history in Scotland and North America. In 2014 the Scottish Heritage Centre of Laurinburg, North Carolina presented him with the Saltire Award for his 'outstanding contributions to the preservation and interpretation of Scottish history and culture' and he is currently the Technical Lead in the Digital Innovation Lab at the University of North Carolina, Chapel Hill.

An early draft of this paper was presented as the seminar text at the 2013 annual conference of the Celtic Studies Association of North America. I wish to thank David Anderson of Williamstown for finding information about the poet and passing it along to me, and an anonymous reviewer of the article who provided a great deal of valuable information and advice about difficult aspects of, and mistakes in, the original Gaelic text. I particularly wish to express my gratitude to the late Kenneth McKenna for providing me copies of Gaelic materials from Glengarry and the encouragement to look into them; this article is dedicated to his memory.
\end{abstract}


received any previous scholarly notice. It is framed as a dialogue between the poet and a goat who meet in a Gaelic township in Ontario and engage in a long discussion about life in the old Highlands. ${ }^{4}$ This dialogue provides interesting insight into the perceptions of Highland immigrants in Canada about their past and present, as refracted through Gaelic literary tradition.

Song-poems are arguably the most popular form of personal and cultural expression in Scottish Gaelic communities and constitute one of the most important means of recovering and understanding the mentalities and communal experiences of Gaels in North America:

Until recently, songs were constantly present in the lives of people. ... The occasions for singing were so numerous that Gaelic song-and the social and affective content of the verses - has over generations inevitably made up a large part of the inner verbal dialogue among many traditional Gaels. ${ }^{5}$

The song-poem edited, translated and analyzed in this article was likely one of those performed by Gaelic speakers in Glengarry at céilidhs and other social gatherings. In fact, the poem itself alludes to the convivial sharing of oral tradition along with alcohol such as might happen at a house or tavern (lines 45-52). That the song was enjoyed by others in Glengarry is also confirmed by its appearance in a local newspaper.

\section{Source and Author}

This song-poem was composed by Alasdair MacGilleMhaoil (Alasdair mac Eóghainn mhic Ghill-Easbuig mhic Domhnaill Duinn). His father belonged to the branch of Lochaber MacMillans known as Clann Iain Léith na Coille; his mother, Eamhair NicGilleMhaoil (Eamhair nighean Gill-Easbuig mhic Eóghainn mhic Dhomhnaill Mhóir) belonged to Suaineart (anglicized "Sunart"). ${ }^{6}$ Alasdair was born in 1764 in Reisibol, Suaineart but was raised in Lochaber from a young age. In 1802 he left Gleann Cinnidh (anglicized "Glenkingie") in Lochaber for Gleann Garadh (Glengarry), Ontario, with many others of the region. He lived at 
E1/2 of lot 10-8th in Kenyon Township ${ }^{8}$ until he passed away in 1853.

I have two sources for the text of this song-poem. The first is an extremely rare booklet entitled Òrain le Alasdair MacIlleMhaoil an Gleann a Garaidh, an Canada-Ard printed in Inverness (Scotland) by the Highlander Office in $1882 .{ }^{9}$ The original copy of the booklet suffered some damage and the print is sometimes hard to read. In the photocopy of the booklet that I have, several words have been marked out and alternative words written near them. There are a total of eight poems on the fifteen pages of the booklet, and all text in the booklet is in Gaelic with no English translation. This is the first poem, appearing on pages three through six. I rate the quality of MacGilleMhaoil's poetry to be of a high calibre.

I also have a photocopy of this song-poem (also in Gaelic only) from a bundle of local newspaper clippings collected by John Roderick MacLeod ("Big Johnny Duncan") of Glen Nevis. The late Kenneth MacKenna gave me a copy of these clippings in 2000. No source details were noted on the pages, so it is not possible to say for certain if a local newspaper printed the song before or after the booklet was printed in Scotland. Given that the texts are exactly the same-including punctuation and typos-one must have been copied directly from the other or from a common written source.

The sources do not indicate the air to which the song should be sung, although the metre is used in other heroic songs of the seventeenth and eighteenth centuries for which melodies survive. One such example is "Moch 's a' Mhadainn Di-Domhnaich" by Murchadh Mór mac 'ic Mhurchaidh $(\dagger 1689) .{ }^{10}$ Likewise, there is no extant information about the sources for these texts, whether they were written down during the lifetime of the poet or transcribed from an oral source much later. The three decades that passed between the death of Alasdair MacGilleMhaoil and the publication of his poems may account for some of the anomalies in the text.

One apparent anomaly is the inconsistency between the information in the foreword to the poem and the poem itself. The foreword states that the poem was composed after the poet purchased a pair of goats while the poem itself mentions the acquisition of only one goat. Imperfect memory or information may 
account for this discrepancy, but as a work of the imagination, poetry does not have to be true to reality: the historical account and context is understood to be the function of the prose seanchas that accompanies song performance. ${ }^{11}$

\section{Literary Form and Themes}

This poem takes the form of a conversation between the poet and a goat. Although it might be tempting to consider the goat a proxy for an actual person, the human-animal dialogue is a well-established literary device we are clearly not meant to take literally. This literary convention has featured in Gaelic literature since at least the Middle Gaelic "The Colloquy between Fintan and the Hawk of Achill" (from about the eleventh century). ${ }^{12}$ As a framing device it is fairly common in Gaelic poetry of the central Highlands, especially as a means of offering social commentary. The best known example is a complex, multilayered poem dated to the late sixteenth century commonly called Oran na Comhachaig, "The Song of the Owl," in which an owl recalls the glories of olden days in Lochaber to the poet-hunter. ${ }^{13}$ I believe that that poem is one of the major influences on this one.

Several other dialogue-poems featuring animals from the eighteenth century offer similar social commentary. In a poem by Fear Shrath Mhaisidh (of Badenoch), posing as a dialogue between a Highland hunter and a deer, for example, the deer teases the Highlander for having to wear trousers (after the kilt was banned for civilian males in 1746). The poem makes clear political statements about cultural subjugation in several spheres. ${ }^{14}$ Numerous other examples of dialogue-poems of a political nature could be cited.

Most heroic and monumental poetry in Gaelic from this era typically focuses on the elite: specific men or families, and their deeds, lineages, residences, and other associations. This poem contrasts sharply with that pattern and the choice of a goat rather than an animal with associations of nobility or wealth-such as a deer, bull or horse-is surely significant to its message: ${ }^{15}$ "goats were especially associated with the lower ranks of Highland society . . From the mid-eighteenth century onward, first wood preservation, then the new emphasis on sheep, and finally the 
clearances, all combined to eliminate the goat from the Highland economy." 16 Like the poet, the goat has survived being squeezed out of existence in the Highlands even if his existence was never more than meagre. I understand the goat to be a metonym for the most vulnerable portion of the population most influenced by social and economic impositions, the cottars (called in Gaelic coitearan or bodaich), a demographic that formed a sizable element of Gaeldom largely invisible in English and Gaelic sources.

The hyperbolic praise of the goat's machismo and the flattery of the goat as lovable bedmate demonstrate that there is a definite tongue-in-cheek element to the poem. In fact, a mock-heroic tone alternates in the poem with the nostalgic air of an idyllic but irretrievable past. The poet uses the goat to voice a critique of the post-Culloden condition of the Highlands and highlight the divergence of its present state from former times. If my identifications of the voices of the poet and goat are correct, it is the human and not the animal who has detailed memories of the past (who lived where), an inversion of the traditional conventions of the dialogue poem, thus a confirmation of its mock-heroic nature, a mixture of sarcasm and serious commentary.

Gaelic immigrant poetry is a literature full of contrasts: distinctions are typically drawn between Scotland and North America, and past and present, but sometimes also encompass contrasts of youth and old age, domesticated and "wild" landscapes, and so on. ${ }^{17}$ The poet evinces such a polarity when, for example, he highlights the vigour of his youth in Scotland (lines 77-80) and states that he regained this youthful spirit when he gains the companionship of the goat, an avatar of the old Highlands (lines 193-200). While many poets expressed relief at escaping the injustices foisted upon them in Scotland, some of them never lost their attachment to their homeland and looked back longingly at what and who they had left behind. Alasdair seems to be one of those who was less than satisfied with Canada, his adopted home, at least judging by this and another poem in the booklet.

Like a number of other poems composed in North America by Gaels born in Scotland, this text spends most of its time travelling around and commenting on the haunts of the poet's youth in the Highlands rather than in the country where he was residing at 
the time that he composed it. The sense of belonging and of duthchas that pervades the poem is discussed in more detail in the Commentary section below. Place names are central in expressing this sense of place in Gaelic literature ${ }^{18}$ and they permeate many sections of this poem. Natives of this part of the Highlands were particularly vulnerable to clearance and pressures of emigration by the $1760 \mathrm{~s},{ }^{19}$ and this poem offers an important and rare testimony of the names of places that have since passed out of usage and have not otherwise been well documented. This article does not, however, attempt to analyze these place names or compare them to the documentary record.

Despite its lament of the decline of Gaelic glories, the present text is illustrative of the deep continuities in many cultural expressions that can be traced from medieval clan life to settlement in North America in the form of literary conventions, cultural allusions, historical signifiers and humour. Numerous other such literary remains survive and await academic scrutiny to inform us of how immigrant Gaels made sense of their experiences by drawing creatively from the past, particularly from their welldeveloped literary tradition.

\section{This Edition}

The original text has a number of irregularities and typos, and is often missing length marks over vowels. I have made silent emendations to the text in minor manners of spelling, orthography and punctuation. I have provided the original text in endnotes only when significant changes have been made or speculations have been necessary to make sense of the original source.

One of the challenges in interpreting this piece is that the original text does not indicate which quatrains are in the voice of the goat and which are in the voice of the human (the poet). I have done my best to deduce these, although I believe that this ambiguity is deliberate. Therefore, in the concluding comments, I treat these communities as essentially synonymous unless there is reason otherwise.

\section{Òran}


Rinneadh an t-òran seo a leanas air do'n bhard a bhith àireamh bhliadhnaichean an coilltichean fiadhaich America, gun bhoc no gobhar fhaicinn no gun mhór-dhùil ri am faicinn nis mó; gidheadh, thachair dha bhith cho sealbhach is gun d'fhuair e càraid dhiubh a cheannach bho dhuine uasal do Chloinn Domhnaill a fhuair greim air pàirt dhiubh, ainneamh is gun robh iad ri fhaotainn an Canada aig an àm sin. Air dha na gobhair a thoirt dhachaigh, rinn e an tòran.

$1 \quad$ Latha dhomh air thuras

Am Baile Mhuilinn aig Cloinn Domhnaill,

Dé b' ioghnadh leam a chunna mi

Ach boc nan cluigean òmair;

$5 \quad$ Chuir mi fàilte 's furan air

'S gun d' fhiathaich mi le cuireadhe

'S gun òlainn botal cuide ris

Le sulas a's taigh-òsda.

Dh'fharraid mi 's a' Ghàidhlig dheth

$10 \quad$ Có ás a thàinig bròinein?

Fhreagair e le gàire mi

"'S e sin is cànain dhomh-sa- [a'ghobhar

Rugadh mi 's a' Ghàidhealtach

'S na monaidhean am b' àbhaist duit

15 Bhith siubhal 's gunna 'nad làimh agad

'S tu 'g iarraidh fàth air gòraig."

"Saoil an tusa a chunna mi

[ an duine

Bha fuireach am Beinn Éideann

'S do leannanan 'nan dusanan

20 Am Bruthach nan Clach Éiteag;

'S tric thug thu sgriob gu h-urranta

Ri Sgurr na Cìch' is udalan

Mu d' mhuineal 's ròp gun trusadh ort

'S cha chuireadh iad geall-réis riut."

25 "'S mi mac na goibhre luideagaich [a'ghobhar A rugadh an Druim Chòsaidh; 
$B$ ' eòlach ann an Slat Bheinn mi

'S an Sgurr a' Chlaidheimh còmhladh;

'S tric a bha mi spaisdireachd

30 Mu Choire Gorm nan Cathachan

'S bu dùthchas dhomh bho m' athair

A bhith tathaich am Bràigh Mhórar. ${ }^{20}$

"Cha ruig thu leas bhith 'g innseadh dhomh:

Mu d' shinnsre tha mi eolach;

35 Is fad bho'n tha coir sgriobhte ac'

Air gach frith tha 'n Caledoni;

Bho linn Righ Raibeart fhirinnich

'Chuir iomadh blàr 's cha striochdadhe

Do mhuinntir Shasann, direach

$40 \quad$ Gus an d' islich e fo 'bhròig iad."

"A-nise tha mi 'g aithneachadh

Gum bheil thu sean mion-eòlach

'S gur aithne dhut a h-uile àit'

An tuinicheadh mo sheòrsa;

45 Gun teagamh, bidh mi buidheach dhuit

'S thoir fiosrachadh do'n chuideachd air,

'S ged dh'òlamaid am buideal

'S beag is mutha ${ }^{21}$ oirnn ás ar pòc e."

"Ma tha thu ag iarraidh fiosrach'_ [ an duine

50 Air do chinne, mar a bha iad,

Bheir mise dhut a chlisgeadhe

Mur dèan a' mhisg ar tàladh-

Bha cuid dhiubh tàmh 's a' Sgicideadh

'S bha pàirt am Beinn an Sgritheil ${ }^{22}$ dhiubh

55 'M bràigh Chnòideirt bha na ficheadan

'S bu sgiobalt' iad air fàire.

"Bha móran an Ceann t-Sàile dhiubh

'S gach àite bha mu'n cuairt da;

'S bha cunntas mór gun àireamh dhiubh

60 Air fàrsa Ghlinne Cuaiche; 
Michael Newton

Bu chridheil clann a' gàireachd ann

Gu'n cumail cruinn, 's na màthraichean

'S bu mhilis gruth is càise ann

Is bainne blàth gun truailleadh.

65 "Bha gleadhraich mhór fo Shaod-Bheinn ${ }^{23}$ ac'

Bha Gearraich 's Fraoch-Bheinn làn diubh;

'S bha Gleann Cinnidh saor aca

Gun dad a dhaorsainn màil orr';

Bhiodh coin is gillean caonnagach

70 'Gan tional cruinn gu aon àite

'S bhiodh mnàthan òga saoithreachail

'Gam bleoghann taobh nan àthan.

"Bha 'n Coire Buidhe 's gaol ac' air

Is dh'fhaodadh iad bhith sealbhach;

75 Bha Coire Réidh ri thaobh aca

Gu aodannan nan Garbh-Chrioch;

Bha uaireigin 'am shaoghal

Bha mi sunndach falbhach aotrom ann

Ag ol am bainne, 's shaoileadh tu

80 Gum faodainn a bhith làidir.

"Bha còir air Sgurr nan Ad aca

Gu Srath Cheann Locha Mórar ${ }^{24}$

'S bha Eóghan Bàn 'na Chaiptein orra

'S e tacanan 'nan óban;

$85 \quad$ Gleann İlidh's coire 'n taice ris

Bha Gleann a' Chùil 's an Stac aca

Gleann Taothadail fo fhasgadh dhaibh

'S a ghabhaltas 'nam póca.

"Is chunnaic mi do sheanair

90 Ann am beannaibh Streap a' Chomhlain;

Bha eòlas aige ' $n$ Gabhail ${ }^{25}$ Bheinn

'S bha thadhal mu Loch Beòraig;

Bu mhiann leis a bhith 's t-fhoghar ann

Le buidheann ghorm a thaghadhe 
$95 \quad$ D' an t-seòrsa cheann-ghlas adharcach

'S bu toigh leis bhith 'gam pògadh.

"Bha cairdean dha m'a choinneimh

An Creag Thonachain a chomhnaidh;

'S cha ghluaiseadh iad le gleadhar ás

$100 \quad$ Le gadhar ${ }^{26}$ no le comhstrith;

Iad fhéin 's an àl gu loinneil ann

Bho linn gu linn a' tadhal ann

'S cha tugadh feachd no faoghaid

Port na Craige ${ }^{27}$ dhiubh gu cròdhach.

105 'Bha cairdean daibh a' tathaich

Am Bràigh Ghlastair 's Cill Fhianain ${ }^{28}$

'S bu lionmhor iad le'n dachaigh ${ }^{29}$ ann:

Breac lachdann ballach stiallach;

Bha cuid bha donn is tarr-fhionn diubh

110 'S bha cuid diubh riabhach breac-thàirrneach ${ }^{30}$

'S a' chuid bhiodh fiadhach, ghlacamaid

'Gam fastadh air am fiasaig.

“Bu leò Sgurr a' Ghiubhsachain

'S bu lùthmhor iad ga dhireadh

115 'S na fuarain bhrùchdach dlùth dha sin

Le biolair ùr bu mhilse;

Meall Daimh 'na shruthain dhubh-ghorm,

Bhiodh daimh is aighean siubhlach ann

Is chunna mi le m' shùilean

120 A bhith rùsgadh dhiubh nam bian ann.

"Bha pàirt an Sgurr an Uidheir dhiubh

'S an tuineadh Nead an Fhirein;

Bha cuid an Coire Ghoc-bheinn diubh

Le'm bocaibh 's le'n cuid misleach;

125 Sròin Dhiamhain air a stocadh

Sròin Chorra Bhuilg bu docha leo

$A$ ' ruith nam bileag dosach

Bhiodh air sgorraichean nan stiopall. 
Michael Newton

IRSS 39 (2014)

" $B$ ' aithne dhomh do shìn-seanair

$130 \quad$ 'S cha striochdadh e Righ Deòrsa;

'S gum b' acfhuinneach a dhireadhe

Ri filleadh Sgurra Dhomhnaill;

Bha Sgurra na h-Inghinn sinte ris

'S bha Gleann Mhic Phàil mar stìopan da

135 Gleann Dubh Choirean fo chis aige

'S na milltean ann d'a sheòrsa.

"Bha mac am Beanna Beaga dha

'S fear eile 'n Salachan Ard dhiubh;

Is chunna mi, gun teagamh,

140 Bhith 'gan leigeil air a' Mhànaisreadh,

Maighdeannan is fleasgaichean

'Gan cuallach thun an eadraidh ann;

'S $i$ 'chainnt a b' fheàrr a fhreagradh iad

'S 'hug hug' aca 'gan tàladh.

145 "Bha còir ac' air na Cearcaill

Agus seachad Saor an Daobhaidh

Sloc Molach 'na choir' altraim dhaibh

'S e fasgach air gach taobh dhiubh;

'S bu lionmhor air a' chreachann

150 Ann am Beinn na h-Uamha pailteas dhiubh;

Fear maol's an Eilean Daraich dhiubh

'S thug $m$ ' athair ás air thaoid e.

"Bha mac do'n fhear mhaol dhonn sin

Ann an Goirbheinn Glas an taobh sin;

155 'S bha 'm Bruthach Liath gun toirmeasg ${ }^{31}$ dha

'S dà thaobh an Tairbeirt daonnan;

Bha 'chriochan farsaing falbhanach

Car-son nach biodh e mordhalach?

E siubhal 's caitean colgar air

$160 \quad$ Mar shuirgheach stoirmeil aotrom.

“Cuid de'n t-seòrsa b' urramaich 
A' tuineachadh 's a' Bhaodlaich

'S bha cuid dhiubh 'n Gleann Galmadail

Ged shearg iad leis na caoirich;

165 Bha pairt am Beinn na Beithrich ${ }^{32}$ dhiubh;

Cha robh Beinn Iaidean falamh dhiubh;

Dh'òl mise pàirt dhe'm bainne ann

'S dh'ith mi caisein an deagh laosbhuic.

"Bha cuid d'an treud a b'éibhinne

170 'm Beinn Réiseabol a' tàmhachd

'S bha Camus Bhlàthann réidh aca

'S a' choill gu léir 'na fàsaich;

Ach 's mór a chuir e dh'éis orra

Bhith rùsgadh chrann le'n deudaichean

175 Ri gailleann nuair bhiodh feum orra,

'S bha 'n lagh 'nan déidh 's gach àite.

"Cha robh beinn no sléibhte

Nach robh géilleadh dhaibh an Albainn;

'S dh'ainmichinn na ceudan diubh

180 Ach bheir thu céill do m'sheanchas;

Nise bhon a dh'éirich dhuinn

Gun 'thachair sinn ri chéile seo,

Bidh mise 's tusa réidh-sgeulach

Ma théid thu fhéin air falbh leam.

185 “Is mise 'm fear théid comhla riut [a'ghobhar

'S a tha ro dheònach falbh leat

Bhon chuir thu sios air òran domh

Mar bha mo sheòrs' an Albainn;

Mas ann an cath no'n comhrage,

190 An spàinn ${ }^{33}$ na streup a sheòlas tu

Cha dealaich mi ri m' bheò riut

Ach thoir dhomh mo bheòshlaint aimsreil."

"Mhic na goibhre 's urramaich [ an duine

A rugadh 's an tir bhoidhich,

195 Chan eil mi nis gun chuideachda 
'S tu cuide rium an comhnaidh;

'S ann dh'fhàs mi aotrom iollagach

Bhon thréig a h-uile mulad mi,

Tha spiorad air tigh'nn thugam

$200 \quad$ A bha cuide rium 'am oige.

"Nuair théid mi anns an leaba

'S e 'm boc tarr-fhionn bhios mi feòraich;

Gur taitneach leam thu 'n taice rium

Gu carthannach 'gad phògadh;

205 Tha Gréigis agus Laideann

Air am foghlam ann am pailteas leat

'S cha tréiginn air òr Shasann thu

Ged dh'aisigeadh iad dhomh-s'e.

\section{English Translation}

\section{Song}

The following song was made after the poet had spent a number of years in the wild forests of America, without seeing a buck or shegoat and without much hope of seeing them either; however, it happened that he was so lucky as to manage to buy a pair of them from a gentleman of the Clan Donald who got some of them, despite how rare they were at that time in Canada. After he had brought the goats home, he made this song.

$1 \quad$ One day while I was travelling

In Milltown possessed by the Clan Donald

What surprising thing did I see

But the buck-goat of the bronze bells;

5 I bade him welcome

And I greeted him with an invitation

That I should drink a bottle with him

With great exuberance in the tavern.

I asked him in Gaelic

10 Where did the sad-guy come from?

He answered me with a laugh 
"That [Gaelic] is my own language; [ the goat I was born in the Highlands, In the moors that were customary for you

15 To travel with a gun in your hand

While you were sneaking up on a foolish creature."

"I wonder if it was you that I saw [ the man

Who was living in Beinn Éideann?

You had sweethearts by the dozen

20 On Bruthach nan Clach Éiteag;

Often did you boldly take a trip

Up Sgurr na Cìch' with a collar

Around your neck, and a loose rope on you, And they could not beat you in a race."

25 "I am the son of the ragged goat [ the goat

Who was born in Druim Chòsaidh;

Well did I know Slat Bheinn

As well as Sgurr a' Chlaidheimh;

Often was I sauntering

30 Around Coire Gorm nan Cathachan

From my father it is my inheritance/culture [dùthchas]

To frequent the braes of Mórar.

"You don't need to explain to me:

I know about your ancestors;

35 For a long time they have had written charters

For every hunting ground that is in Caledonia;

Since the era of honest King Robert [the Bruce]

Who fought many a battle, and he would not submit

To the people of England, until the exact moment

40 That he brought them down under his shoe."

"Now, I recognize

That you are old and have precise knowledge

And that you are acquainted with every place

That my folk inhabited;

45 Without a doubt, I will be indebted to you - 
Provide information about them to the company [assembled here],

And even if we drink the bottle

The cost for it out of our pocket will be of little consequence."

"If you seek information [ the man

50 About your relations, as they were,

I will give it to you immediately

Unless drunkenness tempts us away [from the topic] -

Some of them abode in Sgicideadh

And some at Beinn an Sgritheil;

55 There were scores in the braes of Knoydart

And they were lively on the skyline.

"There were many of them in Kintail

And everywhere around there;

And there was an innumerable slew of them

60 Round about Glen Quoich;

It was cheerful to hear children laughing there

Kept together in a group, and their mothers;

Curds and cheese were delicious there

And warm milk, unsullied;

65 "They caused a tremendous clangour under Saod-Bheinn Gearraich and Fraoch-Bheinn were full of them;

They had the freedom of Gleann Cinnidh,

With no oppression of rent on them;

Dogs and pugnacious lads

70 Would gather them [the goats] together in one place;

And young, industrious women

Would be milking them [goats] next to the kilns.

"There was the Coire Buidhe, and they loved it, And they had the chance to be prosperous;

75 They had Coire Réidh next to it, Up to the edges of the Rough Bounds;

There was a time in my life 
When I was happy, carefree and footloose there Drinking their milk, and you would think

80 That I could be strong.

"They had the [land] rights to Sgurr nan Ad

To the strath of the head of Loch Mórar;

And Eóghann Bàn was their leader

While he was for a time in their harbours;

85 They had Gleann Ìlidh and the corrie next to it, Gleann a' Chùil and the Stac was theirs;

Gleann Taothadail was a shelter for them

And they had a lease in their pocket.

"And I saw your grandfather

90 In the peaks of Streap a' Chomhlain;

He was familiar with Gabhal Bheinn

And he travelled around Loch Beòraig;

He delighted to be there in the autumn

With a dark-coloured group that he would choose

95 Of the horned, grey-headed breed,

And he loved to kiss them.

"He had relations across from him

Living in Creag Thonachain;

And they would not move out of there with a [frightening] noise

100 Due to a hunting hound or conflict;

They themselves and their offspring were elegant there

From generation to generation frequenting there,

And neither war-troop nor hunting party

Could take Port na Creige from them by force.

105 "Their relations were frequenting

Bràigh Ghlastair and Cill Fhianain

And they were plentiful by their home being there, Speckled, swarthy, spotted, streaked;

Some of them were brown, and some white-bellied,

110 And some of them were grizzled and speckle-bellied, 
Michael Newton

And we could capture those that were wild Tethering them by their beards.

“They owned Sgurr a' Ghiubhsachain And they were vigorous in climbing it

115 With the gushing springs close to that With the sweetest fresh watercress; Meall Daimh was [like] dark shiny streams, There would be nimble stags and hinds And I saw with my [own] eyes

120 Their hides being stripped from them.

"Some of them were in Sgurr an Uidheir In which would be found the eagle's nest; Some of them were in Coire Ghoc-bheinn

With their roebucks and their young does;

125 Sròin Dhiamhain was well stocked;

They preferred Sròin Chorra Bhuilg

Chasing the bushy leaves

That would be on the spurs of the peaks.

"I knew your great-grandfather

130 And he would not yield to King George;

And he would climb well-equipped

Up the folds of Sgurra Dhomhnaill;

Sgurra na h-Inghinn was stretched out against it

And Gleann Mhic Phàil was his stipend,

135 Gleann Dubh Choirean was under his command As thousands of his kin were there.

"He had a son in Beanna Beaga And another of them in Salachan Àrd;

And I saw without a doubt

140 Them being milked at Mànaisreadh, Young women and men

Herding them there to the milking;

The words to which they would best respond

Was their "hug hug" [chorus] as they were being coaxed. 
145 "They had the land-rights to the Cearcaill And past Saor an Daobhaidh;

Sloc Molach was a cauldron of nourishment for them And a shelter all around them;

They were plentiful on the rocky slope

150 And loads of them on Beinn na h-Uamha;

A hornless one in Eilean Daraich

Who my father took out with a tether.

"That brown, hornless one had a son

On that side of Goirbheinn Glas;

155 And Bruthach Liath was his without hindrance

And both sides of Tarbert always;

His territory was extensive and well-travelled

Why wouldn't he be pompous

As he travelled, with his rugged fleece

160 Like a tempestuous, light-footed wooer.

"Some of the most noble of that kin

Were living in Baodlach

And some of them in Gleann Galmadail

Although they have dwindled with the sheep;

165 Part of them were in Beinn na Beithrich

Beinn Iaidean did not lack them;

I drank some of their milk there

And I ate the dewlap of the goodly goat.

"Some of the most joyful flock

170 Were living in Beinn Réiseabol

And they had the freedom of Camus Bhlàthann

When the entire forest was a wilderness;

But it was much to their detriment

To be stripping trees bare with their teeth

175 During a storm when they [the goats] needed

them [the trees],

And [estate] law was [enacted?] after

them everywhere. 
"There was no mountain or moorland

In Scotland that did not yield to them;

And I could name hundreds of them,

180 If you would only understand my lore;

Now, since it has happened

That we have encountered each other here

You and I will be reconciled

If you yourself leave with me.

185 "I'm the one who will go with you indeed [ the goat

And who is most willing to accompany you

Since you have recorded in a song for me

How my kin were in Scotland;

Whether it is to warfare or battle,

190 Or to strife or conflict that you proceed,

I will never part from you all my life

If you only give me my seasonal earnings."

"O son of the most noble goat [ the man

Who was born in the beautiful land,

195 I am now not without company

So long as you stay with me;

Indeed, I have become light-hearted and frolicsome

Since every sorrow has left me;

A mood has come to me

200 That I had in my youth.

"When I go to bed

It is the fair-bellied buck I will be asking for;

I enjoy having you next to me,

Kissing you affectionately;

205 Greek and Latin

You have learned in abundance

And I would not abandon you for England's gold

Even if they carried it over to me." 


\section{Commentary}

This poem reflects the insecurity over land tenure, which enabled landlords and bureaucrats to remove so many Gaels-particularly the most vulnerable - from their ancestral habitations. There are several references in the poem to inhabitants having the rights to their land (lines 81 and 113), enjoying unhindered occupation (lines 67-8, 155-6 and 171), and sometimes even possessing written charters (lines 35-6 and 88). The poet also contrasts the present with the times when tenants could not be removed from land by force (lines 99-104). On the other hand, he mentions the negative consequences of the introduction of sheep (line 164).

There is, furthermore, a strong emphasis on the long-term occupation of land and sense of attachment to it, reflected, for example, in the term duthchas (line 31 ) and the intimate knowledge of territory and inhabitants that people had (lines 27-8, 41-4 and 101-2). Like Òran na Comhachaig (and many other Gaelic texts), this poem delights in enumerating the names of locations where people lived and some of the associations of those locales, displaying a very strong sense of place. It is notable, in this regard, that the poem begins by naming the township of its origin as a place in the possession of Clan Donald.

Going back in time to the poet's (and the goat's) Scottish homeland, the inhabitants of the Highlands are portrayed as vigorous and healthy from their right relationship to land (e.g., lines $56,61-4,69-74,76-80,77-80,101,114-16,147$ and 167-8). The description of the noble goat travelling extensive territories "like a wooer" (lines 157-60) puts us in mind of the literary conceit of the ruler married to the female personification of the land. ${ }^{34}$ Like Oran na Comhachaig (and many other Gaelic texts), well-being, selfreliance and individual freedom is expressed by depictions of hunting scenes (lines 14-16, 69 and 118-20). As noted previously, this song-poem makes a notable departure from its predecessors and most of its contemporaries by highlighting the mundane activities of the lowest rank of the social order, the cottars who kept goats. Nearly all of the main characters in this poem are these unnamed serfs or goats but they are cast in a positive, nearly heroic, light. 
There must be a reason why particular place names are mentioned by the poet but it is hard to recover today. I suspect that these may be townships that where evictions took place and/or where the author had relations. The meanings of some of the place names conjure an heroic and sovereign past (such as in line 28). The emblem of the MacDonalds was the heather, which is part of the place name of Fraoch-Bheinn (line 66). The poet mentions the area where he was raised near the beginning of the poem (line 67) and the piece culminates with the area where he was born (line 170).

It is also noteworthy, regarding perceptions of cultural subjugation, that the poem reflects a strong sense of Scottish nationhood, when King Robert the Bruce is praised for unyielding resistance to English domination (lines 37-40) as well as when allegiance to the Jacobite cause is applauded (line 130). The mention of "Caledonia" (line 36) suggests the influence of contemporary Anglophone literature, although Robert the Bruce is the best attested Scottish king in Gaelic oral tradition ${ }^{35}$ and his appearance in this piece does not in itself give cause to suspect cultural or literary cross-contamination.

The poet makes some interesting comments on the importance of oral tradition in preserving communal memory: first, in the request to have the knowledge about the associations between people and place recounted (lines 41-8); second, in the thankfulness that these associations were encoded in song form (lines 177-8). In fact, the bond that forms between the poet and the goat (who promises to accompany the poet in his future adventures and even share his bed (line 201), a traditional conceit of the Gaelic literati) ${ }^{36}$ is reminiscent of the relationship between patron and poet (or that of the leader of the war-band and member of his retinue), except that the roles have been reversed: here it is the poet who is going off for adventures, and the warrior (presumably the role of the goat) who will accompany him.

There is scant information about goat-keeping in Gaelic sources or the lives of those who were engaged in this segment of the economy: "vital occupations such as tilling the land are dismissed as undignified or worse. . . The same attitude evidently applied to goats." 37 This song-poem provides a rare but narrow 
window in this world, depicting the large numbers of them in the Highlands (lines 55-62, 107, 136, 149-50, 165-6 and 177-9), their rounding up (lines 70-2 and 141-2), their milking (lines 72 and 140 ), and the critical sustenance produced by them (lines $63-4,79$ 80 and 167). There were increasing conflicts over woodland resources in the post-Culloden era, however, and many trees died after having the bark stripped from them (as intimated in lines 1736). ${ }^{38}$ Goats were usually proscribed by estate "improvers" due to the damage they did to woodlands. ${ }^{39}$

The description of Sloc Molach as a "cauldron of nourishment" or fosterage (line 147-8) is a play on words that appears as a motif in other seventeenth- and eighteenth-century Gaelic poetry praising the landscape. ${ }^{40}$ The Gaelic term coire refers to both a cauldron where food is cooked for consumption and a feature of the landscape, a "corrie" mountain to form a round hollow. This ambiguity emphasizes the ability of the land to sustain its inhabitants generously.

It is, however, the ridiculousness of the idea a goat excited about serving as a warrior-companion that returns us to the mockheroic aspect of the poem, reminding us that the Heroic Age of Gaeldom is now actually over, despite its vibrancy in literature. Nor would we expect the lowest class of Gaelic society to know Greek and Latin (line 205), normally the preserve of aristocratic learning. The "gold of England" refused at the very end of the poem invokes the chase of Prince Charles Edward Stuart across the Highlands after the defeat of the Jacobite army at Culloden and the failure of the Jacobite cause. That the poet could value the goat as highly or more as the head of the Prince is either a satirical comment about nobility, an elevation of the lowest order of Gaelic society, or both.

This poem, then, is an important testimony to both the continuities of Gaelic tradition-transplanted from the Scottish Highlands to numerous communities in North America, including Glengarry, Ontario - and the discontinuities, as Gaels were forced to reconcile the heroism of their past as a proud, independent people with the broken world in which they found themselves.

\section{Further Notes}


Line 76: Garbh-Chriochan "Rough-bounds" was the term commonly used in Gaelic for the geographical Highlands of Scotland into the nineteenth century. However, it was also used in a more restrictive sense for the western parts of Inverness-shire of Knoydart, Morar, Arisaig and Moidart.

Line 83: Eóghann Bàn is not an uncommon name in Lochaber, and there are several possible candidates for who is intended by this allusion. Probably the strongest candidate is Eóghann Bàn Chalpa, who died in 1840 at Callart. He had been the foster-brother of John Cameron of Fassiefern (1771-1815), colonel of the Gordon Highlanders. $^{42}$

\section{Notes}

${ }^{1}$ The most complete modern study of the early Highland settlement is Marianne McLean, The People of Glengarry: Highlanders in Transition, 1745-1820 (Toronto and Kingston: McGill-Queen's University Press, 1991).

${ }^{2}$ Charles W. Dunn, Highland Settler: A Portrait of the Scottish Gael in Cape Breton and Eastern Nova Scotia (Wreck Cove, Cape Breton: Breton Books, 1991).

${ }^{3}$ Professor Robert Dunbar has informed me that there are two poems by Am Bard MacGilleathain which are 216 lines long.

${ }^{4} \mathrm{I}$ am certain that this township was Alexandria, which was known in Gaelic as Muileann an t-Sagairt. Both the English and Gaelic names of the town were named for the Rev. Alexander Macdonell (1762-1840). ${ }^{5}$ John Shaw, Brigh an Orain: A Story in Every Song (Montreal and Kingston: McGill-Queen's University Press, 2000), 13.

${ }^{6}$ This information appears in the private booklet of poems from which this selection is taken; some of it can also be found in Somerled MacMillan, Bygone Lochaber: Historical and Traditional (Glasgow: Davidson \& sons, 1971), 85-7. His patronymic and dates can also be found in the Gaelic periodical Mac-Talla 3 no. 26 (29 December 1894), 8.

${ }^{7}$ Although the original form seems to be Gleann Garadh, Canadian Gaelic sources alternate between Garadh and Garaidh.

${ }^{8}$ The location of his home was passed on to me by David Anderson of Williamstown and came from the records of Harold MacMillan. 
${ }^{9}$ There is no entry for it in Mary Ferguson and Ann Matheson, Scottish Gaelic Union Catalogue (Edinburgh: National Library of Scotland, 1984).

${ }^{10}$ Sung by William Matheson on track ten of side two of Scottish

Tradition 16: William Matheson, Gaelic Bards \& Minstrels (Edinburgh: School of Scottish Studies, 1993).

${ }^{11}$ Shaw, Brigh, 14.

${ }^{12}$ Pat Menzies, ed., Òran na Comhachaig (Edinburgh: Scottish Gaelic Texts Society, 2012), 24.

${ }^{13}$ Menzies, Oran.

${ }^{14}$ Paruig Mac an Tuairneir, ed., Comhchruinneacha do dh'Òrain Taghta Ghàidhealach (Edinburgh: T. Stiubhard, 1813), 332-4.

${ }^{15}$ Another poem by Alasdair MacGilleMhaoil (on pages 14-15 of the booklet) is written as though to a bull.

${ }^{16}$ B. R. S. Megaw, "Goat-Keeping in the Old Highland Economy," Scottish Studies 7 (1963), 201-09 and 8 (1964), 214, 208.

${ }^{17}$ Robert Dunbar, "Poetry of the Emigrant Generation," Transactions of the Gaelic Society of Inverness 64 (2004-2006), 32-76.

${ }^{18}$ See discussion in Michael Newton, Warriors of the Word: The World of the Scottish Highlanders (Edinburgh: Birlinn Ltd, 2009), 296-308.

${ }^{19}$ McLean, The People of Glengarry.

${ }^{20}$ Original: "Mhor-thir."

${ }^{21}$ Original: "mo."

${ }^{22}$ Original: "Sgràil." Scrawled next to this in the margin is "sgreil."

${ }^{23}$ Original: "Shaod-Bheum."

${ }^{24}$ Original: "Mor-thir."

${ }^{25}$ Original: "Gobhal."

${ }^{26}$ Original: "gaothar."

${ }^{27}$ Original: "Creige."

${ }^{28}$ Original: "Cill-ianain."

${ }^{29}$ Original: "dobhaidh"? Hand-written over this: "daithidh."

${ }^{30}$ Original: "breacairneach."

${ }^{31}$ Original: "tiormasg."

${ }^{32}$ Original: "Beinn na bearaich."

${ }^{33}$ Original: "A Spainn."

${ }^{34}$ Newton, Warriors, 132-4.

${ }^{35}$ John MacInnes, Dùthchas nan Gàidheal: Selected Essays of John

MacInnes, ed. Michael Newton (Edinburgh: Birlinn, 2006), 8, 31, 45, 27173.

${ }^{36}$ Newton, Warriors, 98. 
${ }^{37}$ Megaw, "Goat-Keeping," 217.

${ }^{38}$ Marianne McLean, The People of Glengarry, 55-6; T. C. Smout, Alan MacDonald and Fiona Watson, A History of the Native Woodlands of Scotland, 1500-1920 (Edinburgh: Edinburgh University Press, 2005).

${ }^{39}$ Megaw, "Goat-keeping," 203-5.

${ }^{40}$ Newton, Warriors, 295-96.

${ }^{41}$ The Scots term is a borrowing from Gaelic.

${ }^{42}$ MacMillan, Bygone Lochaber, 87. 
Militia Chieftains 